\title{
The Philosophy of Academic Writing According to Islamic Perspective
}

Nurul Syafiqah Mazlan, Wan Mohd Khairul Firdaus Wan Khairuldin, Hannan Fatini Md. Reshad, Wan Nur Izzati Wan Nor Anas, Abdul Hanis Embong

To Link this Article: http://dx.doi.org/10.6007/IJARBSS/v11-i2/8662 DOI:10.6007/IJARBSS/v11-i2/8662

Received: 20 December 2020, Revised: 17 January 2021, Accepted: 28 January 2021

Published Online: 06 February 2021

In-Text Citation: (Mazlan et al., 2021)

To Cite this Article: Mazlan, N. S., Khairuldin, W. M. K. F. W., Reshad, H. F. M., Anas, W. N. I. W. N., \& Embong, A. H. (2021). The Philosophy of Academic Writing According to Islamic Perspective. International Journal of Academic Research in Business and Social Sciences, 11(2), 195-201.

Copyright: (c) 2021 The Author(s)

Published by Human Resource Management Academic Research Society (www.hrmars.com)

This article is published under the Creative Commons Attribution (CC BY 4.0) license. Anyone may reproduce, distribute, translate and create derivative works of this article (for both commercial and non-commercial purposes), subject to full attribution to the original publication and authors. The full terms of this license may be seen

at: http://creativecommons.org/licences/by/4.0/legalcode

Vol. 11, No. 2, 2021, Pg. 195 - 201

Full Terms \& Conditions of access and use can be found at http://hrmars.com/index.php/pages/detail/publication-ethics 


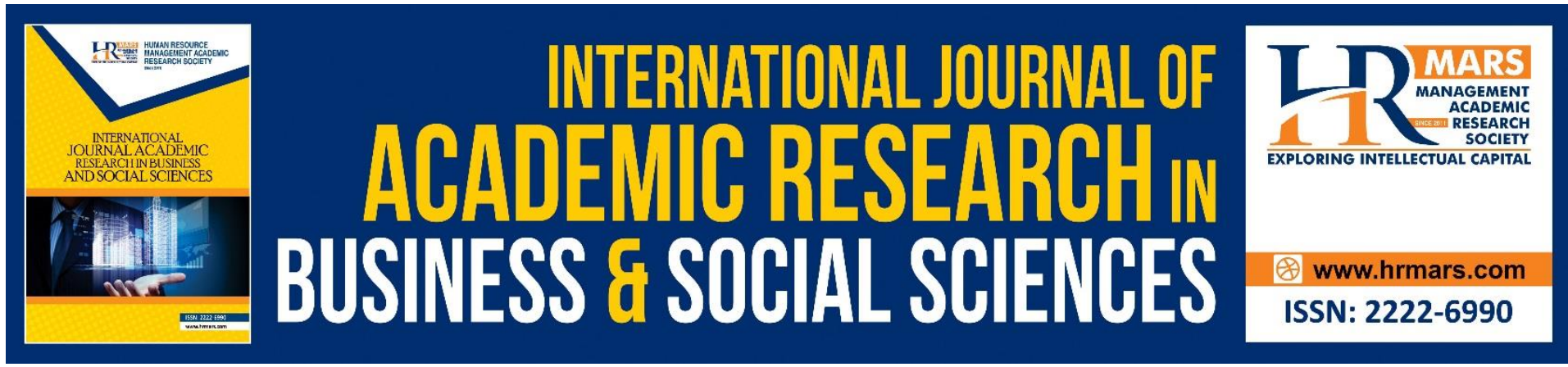

\title{
The Philosophy of Academic Writing According to Islamic Perspective
}

\author{
Nurul Syafiqah Mazlan ${ }^{1}$, Wan Mohd Khairul Firdaus Wan \\ Khairuldin ${ }^{1}$, Hannan Fatini Md. Reshad ${ }^{1}$, Wan Nur Izzati Wan \\ Nor Anas $^{2}$, Abdul Hanis Embong ${ }^{3}$ \\ ${ }^{1}$ Faculty of Islamic Contemporary Studies, Sultan Zainal Abidin University, Gong \\ Badak Campus, Terengganu, ${ }^{2}$ Academy of Islamic Studies, University of Malaya \\ ${ }^{3}$ Centre for Foundation and Liberal Education, University Malaysia Terengganu \\ Email:wanfirdaus@unisza.edu.my
}

\begin{abstract}
Writing is one of the activities that is a must, especially for academic writing. In general, academic writings is necessary based on several interests among them to meet the requirements of the implementation of KPIs and one of the conditions for graduation for postgraduate students. Islamic scholars have always prioritized writing in the integration of knowledge and religion. They use the medium of writing as a whole at first through the writing of books. Currently, the use of social media and websites is continued to achieve that objective. Therefore, Islam details some special philosophies so that the writing done not only meets the needs of the world, but also becomes a matter that benefits society. This paper aims to identify the concept of academic authorship and its philosophy according to the Islamic perspective. Document-based data were collected before being analyzed using content analysis methods. The findings of the study found that there are three main philosophies of writing in Islam. First, the true intention. Second, honest. Third, be responsible for the writing produced. This philosophy should be the main ethic to today's academic writing so that the writing produced has a good impact and benefits the community.
\end{abstract}

Keywords: Philosophy, Academic Authorship, Academics, Responsibilities.

\section{Introduction}

Writing is a form of processing and translating ideas into targets. Writing in scholarly or academic writing is a form of authorship performed by academia. Nowadays, writing is carried out individually or in groups. This matter is no stranger and has become a culture in the academic world today (Mazlan \& Khairuldin, 2018: 363). This practice is very beneficial because it is able to maximize the diversity of ideas and fields of each author (David, 1993). In fact, in another angle, group writing is able to produce more quality and efficient findings. Usually, this practice is done by academics for when practicing the contribution of ideas or involves a variety of fields. 
In general, group authorship for scholarly writing can be defined as writing done by more than one individual in an article (Glaenzel et al. 2004; Katz et al., 1997). This writing is written academically and involves academics or experts in their respective fields. In addition, this writing also sometimes involves field experts when it comes to field studies (Wuchty, Jones, \& Uzzi, 2007). According to Shah (2004), cooperation in writing is a form of aggregation of energy, ideas, knowledge and abilities of each researcher. The work will ultimately produce high input value, creative and innovative compared to individual writing. In addition, this group writing also increases productivity and scientific impact on the writing (Bales et al., 2014; Claudel et al., 2017)

Writing is one of the activities done by Islamic scholars. Islam strongly encourages writing in Islam especially writing that leads to goodness. Apart from writing the Quran and writing hadith, writing has various purposes and uses. Writing is important in the field of knowledge because it is one of the methods to the dissemination of knowledge, storage of information, a symbol of Islamic art.

Writing also has a great impact on Islam (Utusan Online, 2011). Information on the beginnings, development and spread of Islam can be shared and known through writing. Through writing on the history of the writing of the Qur'an, hadith, the writings of Muslim scholars and modern scholars, has shown the seriousness of scholars to gain knowledge and disseminate it to the general public to benefit together. Shared writing can also instill a spirit of love for knowledge, proliferation of ideas, saving time and so on.

\section{Methodology}

As a research methodology, this paper uses library research. Data collection methods and data analysis methods have been specifically defined so that this paper is more organized and systematic. To obtain the data, the method of document analysis is used. According to Jasmi (2012), the method of data analysis is a method to obtain true and accurate information in the form of documents from printed materials. To meet the objectives of this paper, data collection methods are used by analyzing documents in the form of books, journals and pamphlets related to the philosophy of authorship in Islam.

Once the required data has been collected, the data is analyzed through content analysis methods. According to Krippendorff (2004) and Yusof (2004), content analysis is a method of research by drawing conclusions through the acquisition of data in the form of documents. Since this work obtains data in the form of documents, then content analysis is an appropriate method to collect documents related to the philosophy of authorship according to Islam.

\section{Findings}

To make this paper more focused in explaining the data obtained, this paper is divided into two discussions. First, a discussion of the concept of authorship. Second, the philosophy of authorship in academic writing according to Islam.

According to Kamus Dewan (2000), authorship is matters related to the author. Meanwhile, according to Adnan (2008), authorship in writing means the author those who produce ideas or ideas and spread them through books. Authors consist of individuals, groups of people as 
well as bodies or governments that have rights over the work done. This indicates that authorship refers to a subject related to the author i.e. the person who produces the idea of a work that has full rights over the writing or essay produced by him.

\section{The Concept of Authorship in Academic Writing}

For academics, writing is one of the important elements. The importance of writing can be seen through this activity can produce a work or scientific publication. The rising standard of education is now leading to an increase in demand for academic work. According to Zulkifli Abd. Latiff (2013), to implement an assessment of the aspects of learning and teaching academic writing is an important matter that needs to be considered. Meanwhile, Strongman (2014) argues that academic writing is an artistic value that occurs through systematic study and research in reading.

The history of writing has been around since time immemorial and is still evolving to this day. Writing now refers a lot to the history of the Qur'an being written and recorded. The Companions of RA wrote using animal skins, palm fronds and many other tools to avoid forgetting their memorization (Manna 'al-Qattan, 2001; Rahman, 2004). Changes in the times led to changes in writing technology, but the culture of writing still continues to this day. In fact, the necessity of writing is also mentioned in the Quran.

According to Ibn-Kathir (2000), the five verses of surah al-'Alaq warn human beings about the process of human occurrence. Then man is taught things he does not know and Allah SWT raises the rank and glorifies man with knowledge. This is what distinguishes human beings from other creatures of Allah SWT. The gift of the intellect bestowed is to think and increase knowledge as well as avoid ignorance.

\section{The Philosophy of Academic Writing According to Islamic Perspective}

Islam is a religion that promotes good values in human beings. Such good values can be highlighted through philosophy. In general, philosophy is an effort to gain confidence and prosperity through the mind (Hamdan, 2011) In addition, philosophy is the knowledge of researching nature to obtain a truth (Imam, 1998). The meaning of this philosophy is in line with the views of Hashim (2002) who explains philosophy is the feeling of liking true knowledge.

The foundation in philosophy is to love knowledge and truth. Knowledge can also be obtained through authorship. Everyone involved in authorship has their own responsibilities, especially the author or writer as an important pillar in the production of a work. Therefore, good values must exist in every writer to produce high quality writing while having a good personality. This to some extent affects not only the work but also has a good effect on the reader.

Some good values can be applied in authorship, among them is trust. This trait is important because trust will make a person more responsible for the task that has been given. This nature can also prevent a person from being treacherous to the task that has been entrusted.

\section{First, the True Intention}

Every job must have a main purpose. The purpose is in the form of sincere intentions. According to language, intention is a will of the heart (al-Nawawi, 1980). Everything that 
crosses the heart without being accompanied by any action not named as intention. According to Ibn-Hajar (1999), everyone needs to improve their intentions and maintain their morals better. Sincerity is when an obedience purifying the heart from reprehensible traits (al-Jurjani, 1985).

While according to al-Ghazali (1999), true sincerity is when a person becomes a servant of Allah SWT in obedience instead of being a slave to himself and lust. Sincerity also needs to be nurtured in seeking knowledge to increase the level of knowledge. Seeking knowledge is an act of worship, to obtain the blessings and pleasure of Allah SWT.

In addition, clear intentions and goals can lead to one's success. This is because there is a direction in the goal that has been possessed only requires effort to ensure that success can be achieved. According to Covey (2013) and Morris (1994), vision and intention is an aspect that leads to success for an act or job even if it takes a long time.

Sincerity can also stay away from various negative attitudes including riyak, following lust, wanting attention and so on (al-Ghazali, 2001). Every individual, especially academics, should ensure that the intentions in whatever field they are involved in provide benefits not only to themselves, but also to the surrounding community and religion. Practices done with the right intention will be rewarded by Allah SWT. The research conducted must also be based on sincere intentions so as not to deviate from the true path and stay away from the nature of riyak. This is because according to Shuhari and Hamat (2015), if there is a mixture of intentions between the intention to do something because Allah SWT and mixed with other intentions do not considered sincere.

\section{Second, Honest}

The nature of amanah (honest) is one of the commendable qualities that must exist in every individual. Everyone who needs to fulfill the trust that has been given to him as best as possible. Islam calls on its people to have trust.

According to Din (2007), the nature of trust is one of the things that must be done to the person who has received the trust. Doing good to others and giving rights to those who should receive is also considered a trust. This shows that every good deed is also considered a trust because it performs responsibilities by doing good deeds that can facilitate the affairs of others.

Therefore, every researcher must have a fair nature and trust in conducting research. The results obtained from the study are important to ensure that it is in line with the requirements of Islamic law and stay away from things that are contrary to the law of Allah SWT. Research should also be free from biased attitudes which place emphasis on any particular party by abandoning the attitude of trust that should be emphasized.

\section{Third, be Responsible for the Writing Produced}

A responsible attitude must be present in every human being. This attitude shows that every thing that is done must be examined whether there are pros and cons to it. According to Omar (1992), everyone will be responsible for every choice of action taken. If there is good in him, 
then he will be rewarded accordingly. However, if he chooses something bad, there is retribution that is commensurate with the bad he did.

According to Syed Nawab Haider Haqvi (1981), when a person is given the responsibility to carry out a job or task, they need to perform it perfectly to be considered a responsible person. In fact, responsible attitude is also related to human actions (Iqbal,1960). Responsibility places one in an ethical state in Islam. Each member who shares must be responsible in performing their respective tasks.

\section{Conclusion}

In conclusion, academic writing has a great importance to society. It is a liaison of research conducted at the university level for the benefit of the community. Therefore, each writing must follow the correct philosophy so that the writing produced can provide real benefits. Islam has established three main philosophies in writing. the true intention. Second, honest. Third, be responsible for the writing produced

\section{Acknowledgement}

This article is a part of research under Fundamental Research Grant Scheme (FRGS), FRGS/1/2019/SSI03/UNISZA/02/3 (Pembentukan Parameter Kepengarangan Berkumpulan Penulisan Akademik Berintegriti Berteraskan Islam: Penilaian Semula Kepada Dasar Penulisan Akademik di Malaysia), and is supported by the Ministry of Education and Universiti Sultan Zainal Abidin (UniSZA).

\section{Corresponding Author}

Wan Mohd Khairul Firdaus Wan Khairuldin,Ph.D

Faculty of Islamic Contemporary Studies, Universiti Sultan Zainal Abidin, Kampus Gong

Badak, 21300 Kuala Nerus, Terengganu, Malaysia.

Email: wanfirdaus@unisza.edu.my

\section{References}

Hamdan, A. R. (2011). Falsafah \& Pemikiran Pendidikan. Universiti Teknologi Malaysia: Penerbit UTM Press.

Jasmi, K. A. (2012). Penyelidikan Kualitatif Dalam Sains Sosial. Johor Bharu: Universiti Teknologi Malaysia.

Krippendorff, K. (2004). Content Analysis: An Introduction to Its Methodology. California: SAGE Publications Ltd.

Yusof, R. (2004). Penyelidikan Sains Sosial. Kuala Lumpur: PTS Publications \& Distributors.

Adnan, H. M. (2008). Memahami Penerbitan Buku. Medium Publication. Selangor: Bandar Baru Bangi.

Shuhari, M. H., Hamat, M. F., Zin, E. I. E. W., Wahab, M. R., \& Rozali, M. H. (2020). Relationship between al-asma' al-husna and al-sidq according to al-ghazali's perspective in almaqsad al-asna. [Hubungan al-asma' al-husna dengan al-sidq perspektif al-ghazali berdasarkan al-maqsad al-asna] Afkar, 22(1), 35-72

Anas, W. N. I. W. N., Khairuldin, W. M. K. F. W. K., Mohd, H., \& Ali, A. K. (2020). Rehabilitation of Transsexual Based on Preaching Psychology in Islam. International Journal of Disaster Recovery and Business Continuity. Vol. 11 (1), pp. 682-687 
Anas, W. N. I. W. N., Khairuldin, W. M. K. F. W., Embong, A. H., Mohd, H., \& Mokhtar, W. K. A. (2020). Trend of transsexualism problem and its implications towards muslim community in malaysia. International Journal of Pharmaceutical Research, 12(4), 2529 